\title{
贺兰山不同林分调落物微生物群落特征与影响因素
}

\author{
刘秉儒 ${ }^{1,2,3,5, *}$, 张文文 ${ }^{4,5}$, 李学斌 4,5 \\ 1 北方民族大学生物科学与工程学院,银川 750021 \\ 2 黄河流域农牧交错区生态保护国家民委重点实验室,银川 750021 \\ 3 宁夏特殊生境微生物资源开发与利用重点实验室,银川 750021 \\ 4 西北土地退化与生态恢复国家重点实验室培育基地, 银川 750021 \\ 5 宁夏贺兰山森林生态系统国家定位观测研究站,银川 750021
}

\begin{abstract}
摘要:贺兰山是我国重要生态屏障,贺兰山生态森林生态系统保护受到极大关注,森林凋落物及土壤微生物对全球气候变化研 究具有重要意义。目前, 贺兰山不同林分的调落物分解过程中微生物群落结构特征差异、不同调落物化学组成对微生物群落结 构的影响尚不清楚。以贺兰山具有代表性的 3 种林分 (油松林、青海云杉林以及油松-山杨混交林) 调落物为研究对象, 开展调 落物化学组成、微生物群落组成及多样性特征研究, 揭示不同林分凋落物的优势微生物群落特征和影响因子。结果表明, 3 种 林分调落物的细菌和真菌在多个多样性指数之间差异性均不显著, 但是在多样性指数中真菌 PD whole tree 指数显著大于细菌, 真菌 Shannon 指数与 Ghao 1 指数却显著小于细菌。在门水平上不同林分凋落物的微生物优势菌类无显著差异,但在属水平上 差异显著, 而且细菌差异小于真菌, 在各个分类水平上, 调落物细菌和真菌群落组成均表现为油松-山杨混交林<青海云杉林<青 海云杉林, 调落物微生物多样性在青海云杉林中最为丰富。细菌不同节点间连接线负相关数量略大于正相关,真菌则相反。油 松林调落物与其它林分调落物相比, 微生物群落之间联系更加紧密。油松林调落物 OC 含量最大、青海云杉林调落物的 TK 含 量最大、油松-山杨混交林的 TN 含量最大, 且在 3 种林分中显著差异。相关性分析表明 OC、TN、TP、TK 是影响调落物细菌和真 菌群落组成及多样性的主要因素, 几余分析表明不同林分调落物的微生物多样性指数受养分影响, 调落物 OC、TN、TP、TK 是影 响微生物群落组成和多样性的重要因素, 其中 OC 与微生物群落多样性相关性最显著, 是影响调落物细菌和真菌群落组成和多 样性最主要的因子。
\end{abstract}

关键词:不同林分; 调落物; 高通量测序;微生物群落;微生物多样性

\section{Microbial community characteristics and influencing factors of litter in different forest stands in Helan Mountains}

LIU Bingru ${ }^{1,2,3,5, *}$,ZHANG Wenwen ${ }^{4,5}$, LI Xuebin ${ }^{4,5}$

1 School of Biological Science \& Engineering, North Minzu University, Yinchuan 750021, China

2 Key Laboratory of Ecological Protection of Agro-pastoral Ecotones in the Yellow River Basin, National Ethnic Affairs Commission of the People's Republic of China, Yinchuan 750021, China

3 Key Laboratory for the Development and Application of Microbial Resources in Extreme Environments in Ningxia Province, Yinchuan 750021, China

4 Breeding Base for State Key Laboratory of Land Degradation and Ecological Restoration in Northwestern China, Yinchuan 750021, China

5 Ningxia Helan Mountains Forest Ecosystem Research Station, State Forestry Administration, Yinchuan 750021, China

\begin{abstract}
Helan Mountains is an important ecological barrier in China, Enhancing the protection of ecological forest 基金项目:国家自然科学基金项目(32060280); 宁夏重点研发计划项目(2018YBZD0482,2018BFG02002); 中央高校基本科研业务费北方民族大 学高层次人才引进科研启动项目 (2019KYQ001)

收稿日期: 2020-08-02; 采用日期:2021-08-06

* 通讯作者 Corresponding author.E-mail: bingru.liu@163.com
\end{abstract}


ecosystem in Helan Mountains has received great attention. Litter is the main source of soil nutrients, and forest litter and soil microorganisms are of great significance to the study of global climate change, while Difference of microbial community structure in litter decomposition of different forest types in Helan Mountains and the influence of different litter physical and chemical groups on microbial community structure are not fully revealed. In this study, composition and diversity characteristics of microbial communities in litter of Qinghai spruce forest, and Pinus tabulaeformis, and mixed forest of Pinus tabulaeformis and Populus davidiana were studied, sampling routine methods and high throughput sequencing methods were used to reveal difference in chemical composition, microbial community composition and diversity characteristics, and explore impact factors of advantage. Results showed that organic carbon content was the largest in the three kinds of forest litters, total phosphorus, the contents of organic carbon, total nitrogen and total potassium in the litter of Pinus tabulaeformis forest, coniferous and broad-leaved mixed forest and Picea crassifolia forest were the largest, and the differences were significant. The $\mathrm{C} / \mathrm{N}$ and $\mathrm{C} / \mathrm{P}$ ratios of the litter of Pinus tabulaeformis forest were significantly higher than those of the other two stands, and the value of N/P ratio of the litter of Picea crassifolia forest was significantly lower than that of the other two stands. There was no significant difference in dominant fungi at phylum level among different stands, but there was significant difference at genus level, and the difference of fungi was greater than that of bacteria. At each classification level, the composition of bacteria and fungi community was as follows: coniferous and broadleaved mixed forest $<$ Pinus tabulaeformis $<$ Picea crassifolia forest, and the diversity of microorganism in the litter of Picea crassifolia forest was the most abundant. Correlation analysis shows that organic carbon, total nitrogen, total phosphorus and total potassium are the main factors affecting the composition and diversity of bacterial and fungal communities. Redundancy analysis showed that the microbial diversity index of litter in different stands was affected by nutrients. Litter OC, TN, TP and TK were important factors affecting the composition and diversity of microbial community. It indicates that OC had the most significant correlation with microbial community diversity and was the main factor affecting the composition and diversity of bacterial and fungal communities in litter.

Key Words : different stands ; litter; high-throughput sequencing; microbial community ; microbial diversity

森林调落物也称为枯落物 (如枯叶、枯枝等), 是连接森林地上植被和地下土壤的重要桥梁, 在森林植被 生长发育过程中起着不可替代的作用 ${ }^{[1-2]}$, 驱动生态系统物质循环和能量流动,作为为土壤最有活力的部分, 调落物是土壤养分的主要来源, 对气候变化具有极为重要的影响 ${ }^{[1,3]}$ 。微生物作为调落物分解过程中最有力 的分解者, 能将植物中的碳氮磷等养分经分解归还到土壤和大气中去, 维持了全球元素的平衡关系, 尤其对碳 平衡维持贡献巨大 ${ }^{[4]}$ 。因此森林调落物及土壤微生物对全球气候变化研究具有重要意义 ${ }^{[5-6]}$ 。调落物的微 生物群落组成和多样性与土壤环境之间是相互影响的 ${ }^{[7]}$, 同时也受自身理化因子的约束 ${ }^{[8]}$ 。研究已表明, 微 生物群落结构主要受到 $\mathrm{pH}$ 、全氮、有机碳等因子影响 ${ }^{[8-10]}$, 有机碳给微生物提供了能源物质 ${ }^{[11]}$, 而氮的有效 性抑制了微生物的生长 ${ }^{[12]}$ 。林分组成 ${ }^{[13]}$ 、环境温度 ${ }^{[14]}$ 、海拔 ${ }^{[15]}$ 、土壤理化性质 ${ }^{[16]}$ 等因素均影响调落物微生 物群落及优势菌类。

贺兰山是我国北方重要生态屏障, 贺兰山生态森林生态系统具有脆弱性, 加强贺兰山的生态保护在我国 受到高度重视, 在贺兰山这一荒漠绿岛森林生态系统调落物的研究较少, 只有赵晓春对贺兰山典型森林类型 凋落物层水文效应进行了研究 ${ }^{[17]}$ 。由于干旱区和风沙区山地森林系统中针叶树种的枝叶中含有较多的油脂 成分, 其调落物中的油脂成分也比较多, 这就导致了它的调落物不易分解, 降解速度慢。那么调落物微生物群 落和其他区域的特征是否一致, 不同林分调落物微生物群落特征与影响因素的研究是否支持上述结论, 尚未 得到验证或揭示。

贺兰山大面积森林类型为针叶林, 针阔混交林所占面积较小, 其中针叶林为油松林和青海云杉林, 针阔混 交林以油松-山杨混交林为主要类型。因此, 本研究拟以 3 个典型林分 (天然林青海云杉林、油松林和油松-山 杨混交林) 调落物为研究对象, 分析研究调落物成分和分解过程中微生物的优势菌类, 揭示不同林型的调落 物分解过程中微生物群落结构特征差异、不同调落物化学组成对微生物群落结构的影响, 这对进一步揭示荒 漠绿岛生态系统物质循环和能量流动过程, 全面理解森林调落物、土壤养分和微生物之间的互作机理, 阐明生 
物地球化学循环、丰富调落物分解里具有极其重要的科学意义 ${ }^{[16-18]}$ 。

\section{1 试验地概况}

研究区地处贺兰山中段东坡苏峪口地段 $\left(38^{\circ} 19^{\prime}-39^{\circ} 22^{\prime} \mathrm{N}, 105^{\circ} 49^{\prime}-106^{\circ} 41^{\prime} \mathrm{E}\right)$, 该区域森林面积 $95.87 \mathrm{~km}^{2}$, 海拔 1500-3000 $\mathrm{m}$ 之间, 属于典型的大陆性气候, 秋季凉爽, 冬季寒冷漫长,夏季炎热短暂,春季 气温回升快, 大风及沙尘天气频繁,无霜期 60-70 d。年均气温 $-0.9^{\circ} \mathrm{C}$, 年均降水量 $287.2-429.8 \mathrm{~mm}$, 主要集 中于 7-9 月。森林土壤类型主要以灰褐土、棕钻土为主。植被类型主要为针叶林、针阔混交林,零星分布的 少量的阔叶林, 以及高山草甸。针叶林主要有油松 (Pinus tabulaeformis)、青海云杉( Picea crassifolia); 阔叶林 主要有山杨 (Populus davidiana)、偶见白华 (Betula platypHylla) 和青杨 (Populus cathayana); 针阔混交林以油 松-山杨混交林最为常见; 林下常见灌木植被有小叶忍冬 (LoniceramicropHylla)、虎榛子(Ostryopsis davidiana)、 小叶金露梅 (Potentilla parifolia) 等 ${ }^{[16]}$ 。

\section{2 研究方法}

\section{1 样地选择和样品采集}

综合考虑宁夏贺兰山森林分布特征和立地条件, 以广布的油松林、青海云杉林、油松-山杨混交林作 (针阔混交比例为 6:1) 为 3 种典型林分开展研究,各林分分别确立 3 块 $10 \mathrm{~m} \times 10 \mathrm{~m}$ 的样地作为重复,样地相对距 离 80-100 m 之间,对样地经纬度、海拔、坡度、坡向、平均树高、平均胸径、林分密度、郁闭度、主要林下植被和 土壤类型等基本特征进行系统调查,各林分生境基本特征见表 1 , 各林分特征及调落物特征见表 2 。在每个样 地沿两条对角线设置 5 个样点混合取样法对调落物层取样, 每 5 个样点采集的未分解调落物和半分解调落物 的混合后的样品为一个调落物样品, 每个混匀的凋落物在现场等分成两份,一份装人经高温灭菌的冻存管, 然

表 1 不同林分样地生境基本特征

Table 1 Basic habitat characteristics of different stands plots

\begin{tabular}{|c|c|c|c|c|c|c|c|}
\hline $\begin{array}{l}\text { 林分 } \\
\text { Forest } \\
\text { stands }\end{array}$ & $\begin{array}{l}\text { 样地位置 } \\
\text { Position of } \\
\text { sample plot }\end{array}$ & $\begin{array}{l}\text { 地理位置 } \\
\text { Geographical } \\
\text { position }\end{array}$ & $\begin{array}{c}\text { 海拔 } \\
\text { Altitude /m }\end{array}$ & $\begin{array}{l}\text { 坡度 } \\
\text { Slope }\end{array}$ & $\begin{array}{l}\text { 坡向 } \\
\text { Aspect }\end{array}$ & $\begin{array}{l}\text { 林下主要植被 } \\
\text { Main undergrowth vegetation }\end{array}$ & $\begin{array}{c}\text { 土壤类型 } \\
\text { Types of soil }\end{array}$ \\
\hline \multirow[t]{3}{*}{ HY } & 藏酒洞 & $\begin{array}{c}38.75305 \\
105.91189\end{array}$ & 2123 & 36 & 79 & $\begin{array}{l}\text { 虎榛子 (Ostryopsis davidiana)、 } \\
\text { 小叶忍冬 (LoniceramicropHylla)、 } \\
\text { 大披针苔草 (Carrex lanceolate) }\end{array}$ & 灰褐土 \\
\hline & 西沟 & $\begin{array}{c}38.74453 \\
105.91469\end{array}$ & 2089 & 34 & 54 & $\begin{array}{l}\text { 小檗 (Berberis amurensis)、 } \\
\text { 莎草(Cyperacites haydenii)、 }\end{array}$ & 灰褐土 \\
\hline & 西沟 & $\begin{array}{c}38.74451 \\
105.91665\end{array}$ & 2103 & 20 & 225 & $\begin{array}{l}\text { 苔草(Carex stenocarpa)、 } \\
\text { 柴胡 (Bupleurum Chinense) }\end{array}$ & 灰褐土 \\
\hline \multirow[t]{3}{*}{ HS } & 点将台 & $\begin{array}{c}38.77617 \\
105.90113\end{array}$ & 2465 & 20 & 219 & $\begin{array}{l}\text { 冷蔽 (Cystopteris fragilis)、 } \\
\text { 达乌里秦艽 (Gentiana dahurica)、 }\end{array}$ & 灰褐土 \\
\hline & 点将台 & $\begin{array}{c}38.77375 \\
105.90089\end{array}$ & 2550 & 25 & 219 & 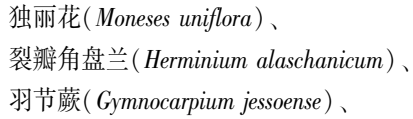 & 灰褐土 \\
\hline & 点将台 & $\begin{array}{c}38.77188 \\
105.89721\end{array}$ & 2667 & 20 & 152 & $\begin{array}{l}\text { 小倾草 (Valeriana tangutica) } \\
\text { 火烧兰(Epipactishelleborine) }\end{array}$ & 灰褐土 \\
\hline \multirow[t]{3}{*}{$\mathrm{HJ}$} & 兔儿坑 & $\begin{array}{c}38.73496 \\
105.91003\end{array}$ & 2330 & 14 & 71 & $\begin{array}{l}\text { 类叶升麻 (Actaea asiatica)、 } \\
\text { 半钟铁线莲 (Clematis ochotensis)、 }\end{array}$ & 灰褐土 \\
\hline & 兔儿坑 & $\begin{array}{c}38.73778 \\
105.91189\end{array}$ & 2249 & 15 & 21 & $\begin{array}{l}\text { 星毛委陵菜 (Potentilla acaulis)、 } \\
\text { 北方鸟巢兰 (Neottia camtschatea)、 }\end{array}$ & 灰褐土 \\
\hline & 兔儿坑 & $\begin{array}{c}38.73531 \\
105.91201\end{array}$ & 2198 & 25 & 98 & $\begin{array}{l}\text { 小蔸( Berberis kawakamii)、 } \\
\text { 黄花(Astragalus membranaceus) }\end{array}$ & 灰褐土 \\
\hline
\end{tabular}

HY :油松林 Pinus tabulaeformis forest;HS:青海云杉林 Picea crassifolia forest;HJ:油松-山杨混交林 Mixed forest of Pinus tabulaeformis and Populus davidiana 
表 2 不同林分及调落物特征

Table 2 Characteristics of different forest stand and litter

\begin{tabular}{|c|c|c|c|c|c|}
\hline $\begin{array}{c}\text { 林分 } \\
\text { Forest stands }\end{array}$ & $\begin{array}{c}\text { 平均树高 } \\
\text { Average tree } \\
\text { height } / \mathrm{m}\end{array}$ & $\begin{array}{c}\text { 平均胸径 } \\
\text { Average diameter } \\
\text { at breast height/cm }\end{array}$ & $\begin{array}{c}\text { 株密度 P } \\
\text { lant density/ } \\
\left(\text { 株 } / 100 \mathrm{~m}^{2}\right)\end{array}$ & $\begin{array}{c}\text { 郁闭度 } \\
\text { Canopy density }\end{array}$ & $\begin{array}{l}\text { 凋落物层特征 } \\
\text { Characteristics of } \\
\text { litter layer }\end{array}$ \\
\hline HY & 10 & 11 & 19 & $0.6-0.7$ & $\begin{array}{l}\text { 调落物层厚度 } 4.9 \mathrm{~cm} \text {, 储量 } 25.21 \mathrm{t} / \mathrm{hm}^{2} \text {, } \\
\text { 平均自然含水率 } 73.95 \%\end{array}$ \\
\hline HS & 9 & 10 & 10 & 0.7 & $\begin{array}{l}\text { 调落物层厚度 } 5.6 \mathrm{~cm} \text {, 储量 } 32.39 \mathrm{t} / \mathrm{hm}^{2} \text {, } \\
\text { 平均自然含水率 } 89.72 \%\end{array}$ \\
\hline HJ & 10 & 11 & 16 & $0.6-0.7$ & $\begin{array}{l}\text { 调落物层厚度 } 4.7 \mathrm{~cm} \text {, 储量 } 19.74 \mathrm{t} / \mathrm{hm}^{2} \text {, } \\
\text { 平均自然含水率 } 76.84 \%\end{array}$ \\
\hline
\end{tabular}

后放人冰盒临时保存, 回实验室后迅速放人 $-80^{\circ} \mathrm{C}$ 冰箱, 用来测定凋落物中的微生物,一份在室温下自然风干 后用于测定凋落物理化指标。

2.2 调落物成分分析方法

对调落物层的有机碳 $(O C)$ 、全氮 $(T N)$ 、全磷 $(T P) 、$ 全钾 $(T K)$ 进行含量分析, 方法如下: SOC 测定采用 $\mathrm{K}_{2} \mathrm{Cr}_{2} \mathrm{O}_{7}$ 容量-外加热法; TN 测定采用凯氏定氮法; TP 测定采用 $\mathrm{NaOH}$ 碱溶-钿锑抗比色法; TK 测定采用火焰 光度法, 具体方法参见文献 ${ }^{[19-20]}$ 。

2.3 微生物多样性测定方法

利用高通量基因组测序技术对细菌和真菌多样性进行分析。本研究采用 $16 \mathrm{~S} r \mathrm{rDA}$ 扩增子测序 (16S rDNA Amplicon Sequencing) 测定细菌多样性 ${ }^{[21-23]}$ 。以 V4 变异区测定细菌群落组成与结构, PCR 扩增所用引 物分别为 806R (GGACTACHVGGGTWTCTAAT) 、515F (GTGCCAGCM GCCGCGGTAA) ${ }^{[24-25]}$ 。以常用的核苷酸 序列内转录间区 (ITS, Internal Transcribed Space) 作为真菌分类鉴定依据 ${ }^{[25]}$, 将 ITS1 区作为测序区域, PCR

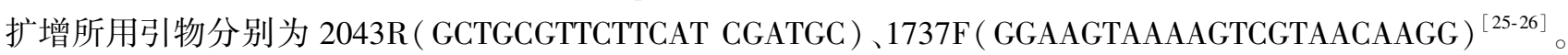
将低温保存的新鲜调落物样品, 在无菌环境下用磁珠法提取试剂盒提取样品基因组 DNA, 操作流程参考 文献 ${ }^{[24,26]}$ 。

无菌水稀释样本 DNA 至 $1 \mathrm{ng} / \mu \mathrm{L}$, 分别以 $16 \mathrm{~S}$ V4 区 $806 \mathrm{R}$ 和 $515 \mathrm{~F}$ 为特异引物, ITS1 区 ITS2-2043R 和 ITS5-1737F 为特异引物, PHusion ${ }^{\circledR}$ High-Fidelity PCR Master Mix with GC Buffer( New England Biolabs 公司)进 行 PCR 扩增。

利用 $2 \%$ 琼脂糖凝胶电泳检测 PCR 产物浓度后进行等量混样,再使用 $1 \times \mathrm{TAE}$ 浓度 $2 \%$ 的琼脂糖胶电泳纯 化,剪切并回收目标条带 (使用 Thermo Scientific 公司生产的 GeneJET 胶回收试剂盒) ${ }^{[24-26]}$ 。

使用赛默飞世尔公司 Ion Plus Fragment Library Kit 48 rxns 建库试剂盒构建文库, 文库经 Qubit 定量检测 合格,就可用 Novogene 生物信息技术公司 Ion S5 ${ }^{\mathrm{TM}} \mathrm{XL}$ 设备开展测序 ${ }^{[24-27]}$ 。

\section{4 数据处理及作图}

用 SPSS 21.0 进行理化指标数据单因素方差分析、差异显著性用 LSD 法比较,理化指标的相关性用 Pearson 相关系数分析, 图形制作使用软件 Origin $2017^{[19]}$ 。

调落物样品的有效数据聚类分析使用 Uparse 软件 (v7.0.1001), 将序列聚类成为 OTUs (Operational Taxonomic Units) 时以 $97 \%$ 的一致性为依据, 然后篮选频数最高的序列作为 OTUs 代表序列。分别在界 (kingdom), 门 (phylum), 纲 (class), 目 (order), 科 (family), 属 (genus), 种 (species) 水平上, 对 OTUs 序列进行 物种注释, 分析各调落物样本的微生物群落组成 ${ }^{[24-25,27]}$ 。

多样性指数 Shannon、Chao1、Goods-coverage、PD whole tree 使用 Qiime 软件 (Version 1.9.1) 计算,绘制稀释 曲线用软件 Origin $2017, \alpha$ 多样性和 $\beta$ 多样性指数组间差异分析使用 R 软件。多样性指数计算公式如下:

(1) 菌群多样性指数( Shannon 指数)

$$
H=-\sum_{i}^{n}\left(\frac{n_{i}}{n} \ln \frac{n_{i}}{n}\right)
$$


式中, $n_{i}$ 为微生物群落中物种 $i$ 的重要值, $n$ 为样品中所有物种的重要值之和 ${ }^{[17,24]}$ 。

(2) 菌群丰富度指数 (Chao1 指数)

$$
\text { Chao } 1=S_{\text {obs }}+\frac{F\left(F_{1}-1\right)}{2\left(F_{2}+1\right)}
$$

式中, Chao1 表示预测 OTU 数目, $S_{o b s}$ 为实测 OTU 数目, $F_{1}$ 表示仅出现一条序列的 OTU 数目, $F_{2}$ 表示出现两 条序列的 OTU 数目 ${ }^{[24-26]}$ 。

(3) 测序深度指数 (Goods-coverage 指数)

$$
\text { Goods-coverageIndex }=1-\frac{F_{1}}{N}
$$

式中, $F_{1}$ 表示仅出现一条序列的 OTU 数目, $N$ 是所有 OTU 丰度之和。根据该公式的含义, Goods-coverage 指 数越高, 则样品中未被测出序列的概率越低 ${ }^{[24]}$ 。

(4) 系统发育多样性指数 (PD whole tree 指数)

该指数是指所检测的调落物样本中,物种对进化历史保留的差异 ${ }^{[25,27]}$ 。因此指数值越大, 表明对进化物 种保存的差异性越大。

\section{3 结果与分析}

\section{1 贺兰山不同林分调落物的微生物 OTU 分析}

贺兰山不同林分调落物的微生物 OTU 数据分析表明,油松林调落物中细菌 OTUs 数目为 2695 个,青海云 杉林调落物中细菌 OTUs 数目为 2967 个, 油松-山杨混交林调落物中细菌 OTUs 数目为 2286 个, 其中共有的细 菌 OTUs 数目为 1478 个,占总数目的 $37.45 \%$ 。

贺兰山油松林调落物中真菌 OTUs 数目为 1243 个, 青海云杉林调落物中真菌 OTUs 数目为 1199 个,油松山杨混交林调落物中真菌 OTUs 数目为 1171 个,其中共有的真菌 OTUs 数目 522 个, 占总数目的 $24.81 \%$ 。

贺兰山青海云杉林特有的细菌 OTUs 数目 624 个,占总数目的 $23.15 \%$,特有的真菌 OTUs 数目 366 个, 占 总数的 $30.53 \%$; 天然油松林特有的细菌 OTUs 数目为 577 个, 占总数的 $19.45 \%$, 特有的真菌 OTUs 数目 422 个, 占总数的 $33.95 \%$; 油松-山杨混交林特有的细菌 OTUs 数目 385 个, 占总数目的 $16.84 \%$, 特有的真菌 OTUs 数目 329 个,占总数目的 $28.10 \%$ 。

\section{2 贺兰山不同林分调落物微生物群落多样性指数分析}

利用 OTU 数目开展细菌和真菌多样性指数的单因素方差分析,结果显示贺兰山不同林分间调落物的细 菌和真菌多样性指数间差异无显著性, 但是调落物的微生物中真菌 Ghaol 指数(丰度指数)、Shannon 指数(多 样性指数) 均显著小于细菌, 调落物的微生物中真菌 PD whole tree 指数 (系统发育多样性指数) 显著大于细菌 (见表 3)。

\section{表 3 不同林分调落物微生物群落多样性指数分析}

Table 3 Diversity index of microbial community in litter of different stands

\begin{tabular}{lccccc}
\hline $\begin{array}{l}\text { 微生物类别 } \\
\text { Types of microbe }\end{array}$ & $\begin{array}{c}\text { 不同调落物 } \\
\text { Litter of different } \\
\text { stands }\end{array}$ & $\begin{array}{c}\text { 丰度指数 } \\
\text { Ghaol }\end{array}$ & $\begin{array}{c}\text { 多样性指数 } \\
\text { Shannon }\end{array}$ & $\begin{array}{c}\text { 系统发育多样性指数 } \\
\text { PD whole tree }\end{array}$ & $\begin{array}{c}\text { 测序深度指数 } \\
\text { Goods Coverage }\end{array}$ \\
\hline 细菌 Bacteria & HY & $1712.67 \pm 528.63 \mathrm{a}$ & $8.46 \pm 1.05 \mathrm{a}$ & $153.26 \pm 30.63 \mathrm{a}$ & $0.98 \pm 0.01 \mathrm{a}$ \\
& $\mathrm{HS}$ & $1808.21 \pm 261.13 \mathrm{a}$ & $8.94 \pm 0.47 \mathrm{a}$ & $155.23 \pm 17.46 \mathrm{a}$ & $0.98 \pm 0 \mathrm{a}$ \\
& $\mathrm{HJ}$ & $1388.5 \pm 226.13 \mathrm{a}$ & $8.2 \pm 0.26 \mathrm{a}$ & $121.93 \pm 18.86 \mathrm{a}$ & $0.99 \pm 0 \mathrm{a}$ \\
真菌 Fungi & HY & $935.05 \pm 92.56 \mathrm{a}$ & $4.91 \pm 0.9 \mathrm{a}$ & $217.49 \pm 23.45 \mathrm{a}$ & $0.99 \pm 0 \mathrm{a}$ \\
& HS & $933.49 \pm 191.73 \mathrm{a}$ & $4.56 \pm 0.27 \mathrm{a}$ & $210.83 \pm 41.6 \mathrm{a}$ & $0.99 \pm 0 \mathrm{a}$ \\
& HJ & $912.96 \pm 93.68 \mathrm{a}$ & $4.43 \pm 0.47 \mathrm{a}$ & $203.24 \pm 29.28 \mathrm{a}$ & $0.99 \pm 0 \mathrm{a}$ \\
\hline
\end{tabular}

表中同列的相同字母表示差异不显著 $(P>0.05)$ 


\section{3 贺兰山不同林分调落物微生物群落组成分析}

在各分类水平上检测 3 种林分调落物的微生物群落组成, 检测到细菌门 33 个, 纲 41 个, 目 89 个,科 169 个,属 377 个; 检测出真菌门 7 个,纲 33 个,目 61 个,科 108 个,属 142 个。调落物的微生物组成在不同林分 间差异较小, 但是细菌群落组成的数量在各分类水平上均显著高于真菌群落组成数量, 并且在门水平、属水平 上差异极显著。细菌、真菌群落组成在各个分类水平上均表现为: 油松-山杨混交林<油松林<青海云杉林 $($ 表 4) ,说明在 3 种林分中青海云杉林调落物的微生物多样性最丰富。

表 4 不同林分调落物的微生物群落结构

Table 4 Microbial community structure of litter in different stands

\begin{tabular}{|c|c|c|c|c|c|c|}
\hline \multirow{2}{*}{$\begin{array}{l}\text { 分类 } \\
\text { Classification }\end{array}$} & \multicolumn{3}{|c|}{ 细菌 Bacteria } & \multicolumn{3}{|c|}{ 真菌 Fungi } \\
\hline & $\mathrm{HS}$ & $\mathrm{HY}$ & HJ & HS & HY & $\mathrm{HJ}$ \\
\hline 门 Phylum & 30 & 29 & 27 & 7 & 6 & 6 \\
\hline 纲 Class & 41 & 40 & 39 & 22 & 21 & 19 \\
\hline 目 Order & 87 & 89 & 79 & 56 & 56 & 54 \\
\hline 科 Family & 164 & 152 & 139 & 98 & 95 & 90 \\
\hline 属 Genus & 359 & 334 & 316 & 125 & 116 & 109 \\
\hline
\end{tabular}

门水平不同林分调落物微生物优势菌群的差异表明,不同林分调落物的微生物中细菌门类前十的丰度基本 相同 (图 1), 优势菌门为放线菌门 (Actinobacteria) 26.6\%、变形菌门 (Proteobacteria) 45.55\%、酸杆菌门 (Acidobacteria) 2.76\%、拟杆菌门(Bacteroidetes) $19.97 \%$ 、共占 $94.88 \%$ 。油松林调落物的细菌优势门类中绿弯菌门 变形菌门的丰度占比较高, 青海云杉林调落物的微生物中细菌门类的酸杆菌门丰度占比较高, 针阔混交林调落 物的微生物中放线菌门在中丰度占比较高。相比而言, 检测到的真菌门类较少 (表 5), 仅占到 $30 \%$ 左右, 在 3 种林分调落物的微生物中真菌主要存在于子囊菌门 (Ascomycota) $29.68 \%$ 、球囊菌门(Glomeromycota) $0.006 \%$ 、 壶菌门 (Chytridiomycota) $0.004 \%$ 、毛霉菌门(Mucoromycota) $0.019 \%$ 。子囊菌门(Ascomycota) 是贺兰山 3 种林 分的调落物中最具优势菌门,而且显著高于其余菌门。同时也发现,枝霉门(Blastocladiomycota) 是油松-山杨 混交林调落物的特有菌门,隐真菌门(Rozellomycota) 是青海云杉林和油松-山杨混交林调落物的特有菌门。

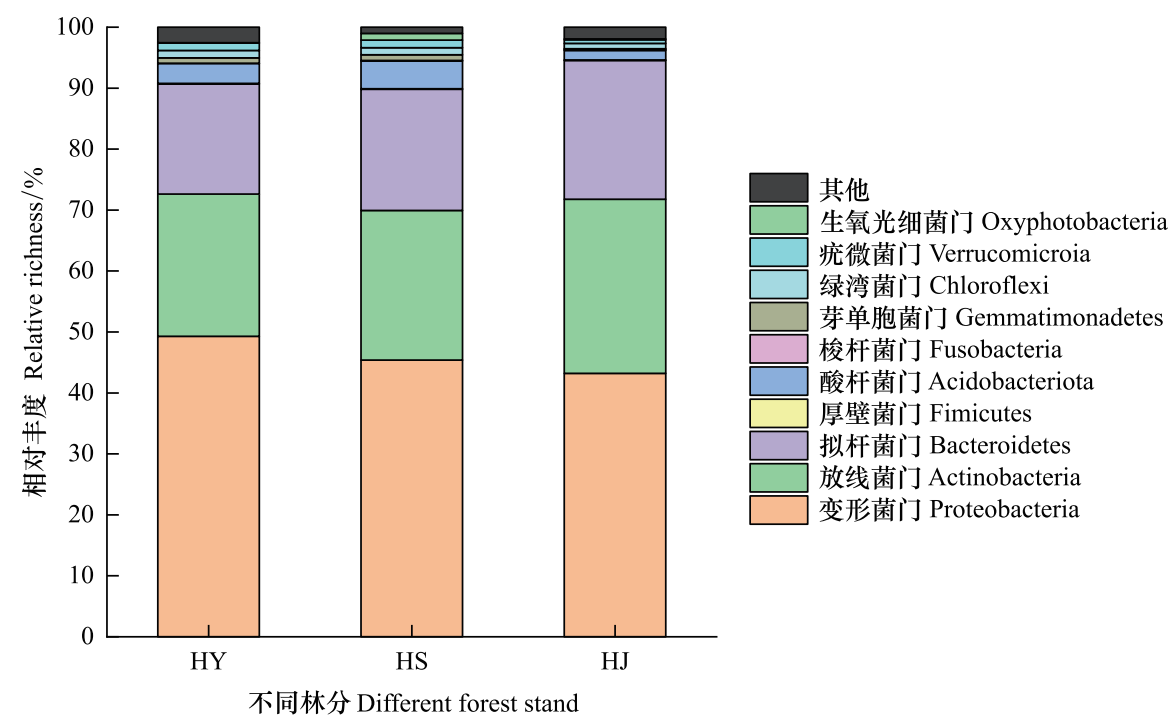

图 1 不同林分凋落物细菌群落丰度前十的细菌门

Fig.1 The top ten bacterial phylum of bacteria Community abundance in different forest litters

HY : 天然油松林 Pinus tabulaeformis forest; HS: 青海云杉林 Picea crassifolia forest ; HJ:油松一山杨混交林 Mixed forest of Pinus tabulaeformis and

Populus davidiana 
表 5 不同林分调落物真菌群落丰度前十的细菌门占比 $/ \%$

Table 5 The proportion of bacteria in the top ten of Fungi Community abundance in different forest stands

\begin{tabular}{|c|c|c|c|c|c|c|c|}
\hline 分类 Taxonomy & HS & $\mathrm{HY}$ & HJ & 分类 Taxonomy & HS & $\mathrm{HY}$ & HJ \\
\hline 子囊菌门 Ascomycota & 28.393 & 24.121 & 36.529 & 芽枝霉门 Blastocladiomycota & 0 & 0 & 0.002 \\
\hline 毛霉菌门 Mucoromycota & 0.011 & 0.015 & 0.03 & 隐真菌门 Rozellomycota & 0.003 & 0 & 0.001 \\
\hline 球囊菌门 Glomeromycota & 0.004 & 0.011 & 0.002 & 单毛壸菌门 MonoblepHaromycota & 0 & 0 & 0 \\
\hline 壸菌门 Chytridiomycota & 0.005 & 0.005 & 0.002 & 其它 Others & 40.246 & 68.67 & 56.962 \\
\hline 油壶菌门 Olpidiomycota & 0 & 0 & 0 & & & & \\
\hline
\end{tabular}

在属水平分析不同林分调落物微生物优势菌群的差异表明, 细菌属丰度占比前十的有结核菌属 (Mycobacterium)、鲸杆菌属( Cetobacterium)、鞘氨醇单胞菌属 (SpHingomonas)、假单胞菌属 (Pseudomonas)、薄 层菌属（Hymenobacter）、unidentified_Burkholderiaceae 菌属、地杆菌属（Pedobacter）、甲基杆菌属 (Methylobacterium) 、成对杆菌属 (Dyadobacter)、内诺卡菌属 (Nocardioides), 其中薄层菌属、甲基杆菌属、地杆 菌属、内诺卡菌属、鞘氨醇单胞菌属、unidentified_Burkholderiaceae 菌属为较具优势菌种,在不同林分间上述优 势菌属占比差异显著 $(P<0.05)$ 。在油松林中鞘氨醇单胞菌属、薄层菌属、甲基杆菌属、unidentified_ Burkholderiaceae 菌属丰度占比最高, 但是在青海云杉林调落物中丰度占比最小; 青海云杉林调落物中特有的 优势菌属是地杆菌属, 油松-山杨混交林调落物中内诺卡菌属和结核菌属丰度占比最大(图 2)。

不同林分间调落物的微生物中, 真菌群落丰度前十的占比差异较大,数据表明 (图 2), 油松山杨混交林 $20.59 \%$ 、青海云杉林 $16.63 \%$ 、油松林 $1.99 \%$ 。青海云杉林调落物中裸盖菇菌属 (Psilocybe) 占比 $13.22 \%$ 、白僵 菌属 (Beauveria) 占比 $3.08 \%$, 这两种菌属是极具优势均属; 油松林调落物中肉片齿菌属 (Sistotrema) 占比 $1.34 \%$ 、Desmazierella 占比 $0.12 \%$ 、丝盖伞属 (Inocybe) 占比 $0.16 \%$, 这 3 种菌属是极具优势均属; 油松-山杨混 交林调落物中 Desmazierella (占比 $20.17 \%$ ) 为极具优势菌属。

\section{4 贺兰山不同林分调落物化学成分与组分分析}

数据分析表明,贺兰山林分调落物的化学成分与组分均存在差异 (表 6)。有机碳 (OC) 是调落物化学组 成的主要成分, 3 种林分中油松林调落物 OC 含量占比达到 36\%, 其它化学组分 ( TN、TK、TP) 占总质量的比值 较小 (均小于 $1 \%$ ), 并表现为 $\mathrm{TN}>\mathrm{TK}>\mathrm{TP}$, 油松林调落物 $\mathrm{C} / \mathrm{N} 、 \mathrm{C} / \mathrm{P}$ 高于其余两种林分的调落物, 且差异显著。 综合来看, OC、TN、TK 分别在油松林、油松一山杨混交林、青海云杉林调落物中含量最高, 且具差异显著性, 青 海云杉林调落物 N/P 低于其余两种林分调落物,且差异显著。

表 6 不同林分的调落物化学成分及组成

Table 6 Chemical composition characteristics of litter in different stands

\begin{tabular}{lccc}
\hline 凋落物化学组成 & HS & HY & \\
Chemical composition of litter & & $360.30 \pm 52.17 \mathrm{~b}$ & \\
\hline 有机碳 $\mathrm{OC} /(\mathrm{g} / \mathrm{kg})$ & $230.00 \pm 9.96 \mathrm{a}$ & $9.16 \pm 0.73 \mathrm{a}$ & $312.70 \pm 7.84 \mathrm{ab}$ \\
全氮 TN/ $(\mathrm{g} / \mathrm{kg})$ & $9.15 \pm 1.25 \mathrm{a}$ & $3.27 \pm 0.2 \mathrm{a}$ & $3.61 \pm 0.1 \mathrm{a}$ \\
全磷 TP/ $(\mathrm{g} / \mathrm{kg})$ & $3.42 \pm 0.32 \mathrm{a}$ & $3.39 \pm 0.66 \mathrm{a}$ & $3.52 \pm 0.23 \mathrm{a}$ \\
全钾 TK/ $(\mathrm{g} / \mathrm{kg})$ & $4.66 \pm 0.18 \mathrm{~b}$ & $39.33 \pm 3.91 \mathrm{~b}$ & $26.37 \pm 0.15 \mathrm{a}$ \\
$\mathrm{C} / \mathrm{N}$ & $25.14 \pm 1.45 \mathrm{a}$ & $110.18 \pm 0.99 \mathrm{~b}$ & $86.62 \pm 0.24 \mathrm{ab}$ \\
$\mathrm{C} / \mathrm{P}$ & $67.25 \pm 0.42 \mathrm{a}$ & $2.80 \pm 0.49 \mathrm{ab}$ \\
$\mathrm{N} / \mathrm{P}$ & $2.68 \pm 0.23 \mathrm{a}$ & $3.29 \pm 0.04 \mathrm{~b}$ \\
\hline
\end{tabular}

同行不同字母表示不同林分间差异显著 $(P<0.05)$

\section{5 贺兰山不同林分调落物微生物群落组成与环境因子的相关性}

贺兰山 3 种林分调落物的化学成分与细菌群落组成的 Spearman 相关性分析表明,在各分类水平丰度前 10 、丰度前 35 进行比较, 然后在分析结果中再次对丰度前 35 的属水平上具有显著相关性的数据进行分析。 结果表明 (图 3), 调落物 OC 与苯基杆菌属 (PHenylobacterium) 和、Iamia 显著正相关, 调落物 OC 与丙酸杆菌 亚属 (Friedmanniella)、黄杆菌属( Flavobacterium)、成对杆菌属 (Dyadobacter)、甲基杆菌属( Methylobacterium)、 


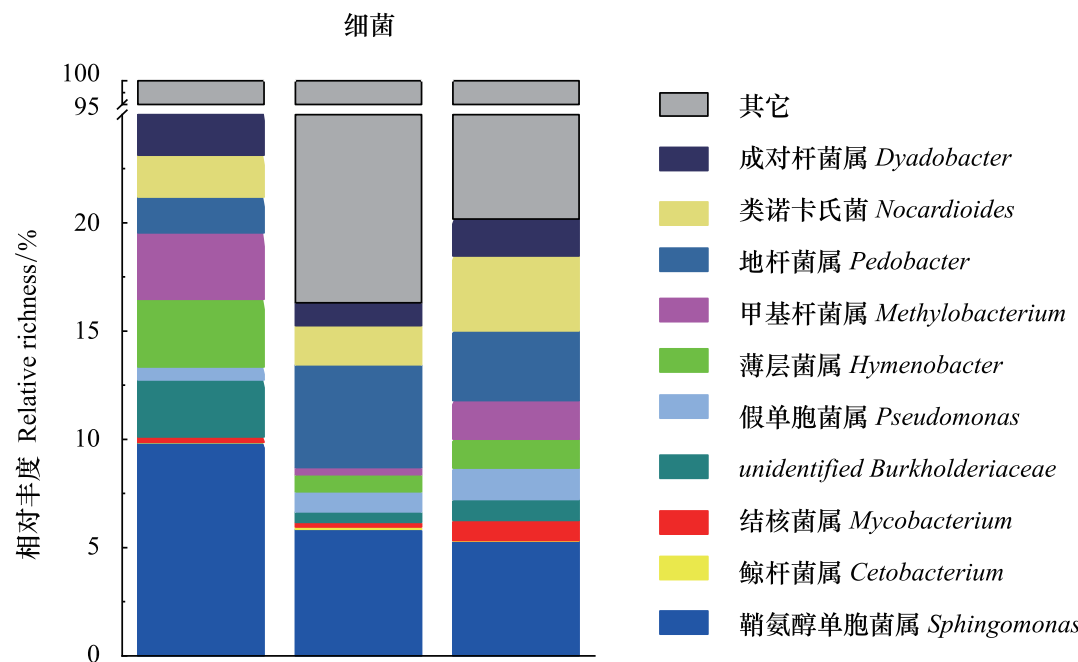

HY

HS

HJ

真菌

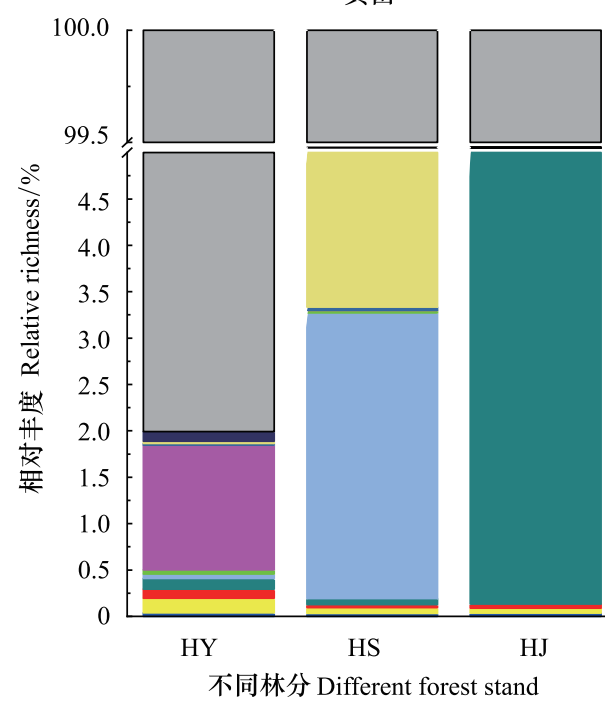

其它

被孢霉属 Mortierella

裸盖菇菌属 Psilocybe

丝膜菌属 Cortinarius

肉片齿菌属 Sistotrema

双担菌属 Geminibasidium

白價菌属 Beauveria

Desmazierella

南极青霉属 Penicillium

丝盖伞属 Inocybe

地星尘菌 Geastrum

图 2 不同林分调落物微生物群落丰度前十的菌属

Fig.2 The top ten species of microbial community abundance in different forest litters

Massilia、Mucilaginibacter、unidentified_Burkholderiaceae 具有显著或极显著负相关性; 调落物 TN 与苯基杆菌属 (PHenylobacterium) 具有显著正相关性,调落物 TN 与黄杆菌属 (Flavobacterium)、TardipHaga、Mucilaginibacter、 unidentified_Rhizobiaceae 具有显著或极显著负相关性; 调落物 TK 与黄杆菌属 (Flavobacterium) 具有显著正相 关, 与短单胞菌属 (Brevundimonas) 具有极显著正相关性。调落物 TP 与短单胞菌属 (Brevundimonas) 具有极显 著正相关性。

贺兰山不同林分调落物的化学成分与调落物的微生物真菌群落组成, 丰度前 35 的 Spearman 相关性分析 结果表明(见图 4), 调落物 OC 与丝核菌属 (Oliveonia)、真菌属 (Serendipita)、Condylospora、Desmazierella、 Yamadamyces 具显著或极显著负相关性; 调落物 TN 与丝核菌属 (Oliveonia)、真菌属 (Serendipita)、蔓毛壳属 (Herpotrichia)、盘双端毛狍属 (Seimatosporium)、Condylospora 具显著或极显著负相关性; 调落物 TP 与黑星菌属 (Venturia)、蜡壳菌属 (Sebacina)、Menisporopsis 具显著或极显著正相关性, 与散斑菌属 (LopHodermium)、Knufia、肉 片齿菌属 (Sistotrema) 具极显著负相关性 $(P<0.01)$; 调落物 TK 与蔓毛壳属 (Herpotrichia) 、丝核菌属 ( Oliveonia)、 Condylospora 具显著或极显著负相关性，与散斑菌属 (LopHodermium)、Knufia 具显著负相关性 $(P<0.01)$ 。 


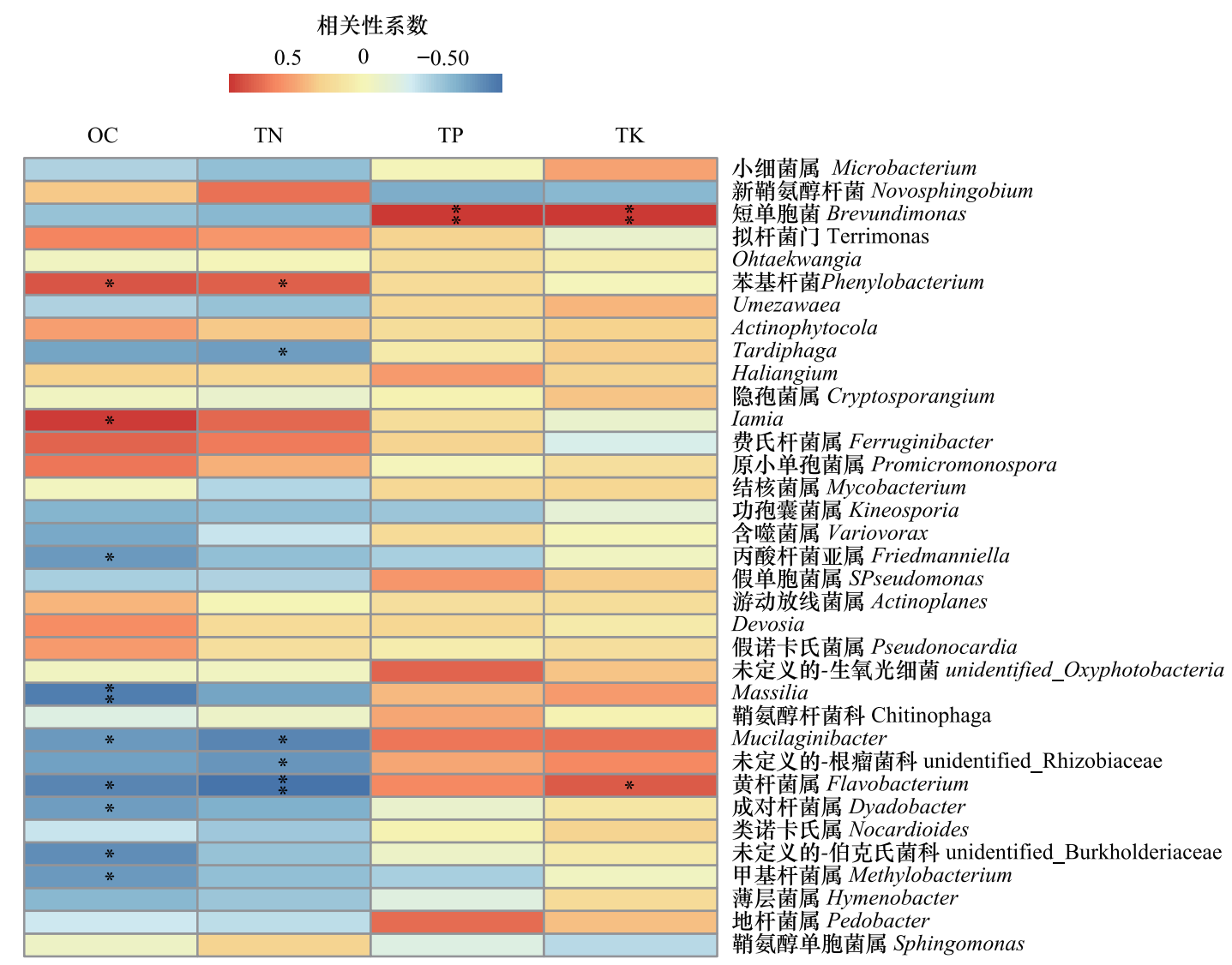

图 3 不同林分凋落物细菌群落属水平与环境因子的相关性分析

Fig.3 Correlation analysis between bacterial community and environmental factors in different forest litters

图中*表示显著相关性 $(P<0.05), * *$ 表示极显著相关性 $(P<0.01)$; OC: 调落物有机碳、TN: 落物全氮、TP: 调落物全磷、TK: 调落物全钾

\section{6 贺兰山不同林分调落物微生物多样性指数和环境因子宇余分析}

贺兰山油松林和油松-山杨混交林调落物的微生物多样性指数分别受 TN 和 TK 影响较大(图 5), 青海云 杉林调落物的微生物多样性主要受调落物 OC 和 TP 含量的影响。综合分析表明,贺兰山不同林分调落物 OC 对细菌和真菌多样性指数影响最为显著 $(P=0.01 、 P=0.002)$ ( 见图 5 )。

3.7 贺兰山不同林分调落物微生物生态网络分析

生态网络可视化图可显示各物种之间的相互关系,贺兰山不同林分调落物的细菌生态网络图表明 (图 6), 油松林调落物中具有最高连接度的细菌为 OTU_110(变形菌门)、OTU_109(放线菌门) 真菌为 OTU_ 207(未分类)、OTU_24(未分类)。青海云杉林调落物中细菌 OTU_109(放线菌门)、OTU_1(变形菌门)具有最 高连接度,真菌 OTU_330 (担子菌门) 、OTU_4490 (未分类)。油松山杨混交林调落物的微生物中, 具有最高连 接度的细菌为 OTU_1076(放线菌门)、OTU_4(变形菌门), 真菌为 OTU_288 (未分类)、OTU_10(子囊菌门)。 不同林分网络节点间连接线正负相关比接近 1 , 但是细菌节点间连接线负相关比例略大于正相关 (图 6), 而 真菌则相反 (图 7)。

\section{4 讨论}

许多学者研究表明,调落物的细菌优势菌门为放线菌门、变形菌门、酸杆菌门和拟杆菌门,本研究中,贺兰 山 3 种林分的这四类细菌优势菌门占细菌总丰度达到 $90 \%$ 以上, 与学者们的研究结论一致 ${ }^{[28-31]}$, 贺兰山调落 物中真菌优势菌门与其他区域森林凋落物中优势真菌门类群基本保持一致 ${ }^{[32]}$, 但是在不同林分间调落物的 细菌和真菌各优势菌门变化幅度较小, 这说明调落物的微生物群落多样性指数在不同林分间均无显著性差 
$\mathrm{OC}$

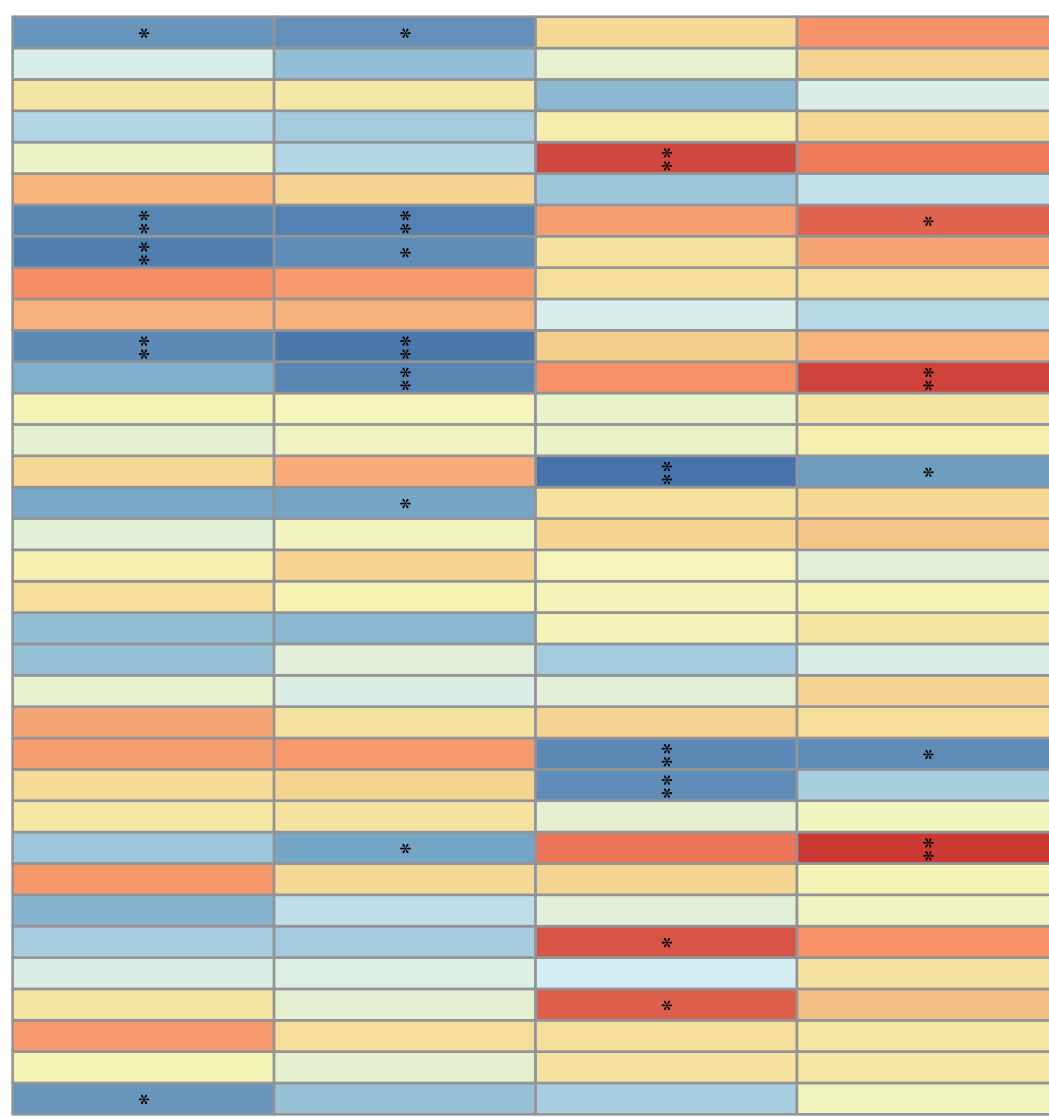

丝核菌属菌属 Oliveonia

Chlamydomyces

Ochroconis

Cystofilobasidium

Menisporopsis

Reticulascus

Condylospora

真菌属 Serendipita

Cladophialophora

Phlebiella

Yamadamyces

丝核菌属 Rhizoctonia

Rhodosporidiobolus

Hyalodendriella

Knufia

盘双端毛抱属 Seimatosporium

Mycoarthris

Naematelia

螺菌属 Neobulgaria

Hypoderma

威氏盘菌属 Wilcoxina

Microthecium

革菌属 Tomentella

散斑菌属 Lophodermium

肉片齿菌属 Sistotrema

斜盖伞属 Clitopilus

蔓毛売属 Herpotrichia

白價菌属 Beauveria

星裂盘菌属 Phacidium

蜡売菌属 Sebacina

小花口壳属 Anthostomella

黑星菌属 Venturia

小菇菌属 Mycena

裸盖菌属 Psilocybe

Desmazierella

图 4 不同林分调落物真菌群落属水平与环境因子相关性分析

Fig.4 Correlation analysis between the level of Fungi Community and environmental factors in different forest litters 图中*表示具显著相关性 $(P<0.05), * *$ 表示具极显著相关性 $(P<0.01)$

○ 油松 $\square$ 青海云杉 $\diamond$ 油松-山杨混交林
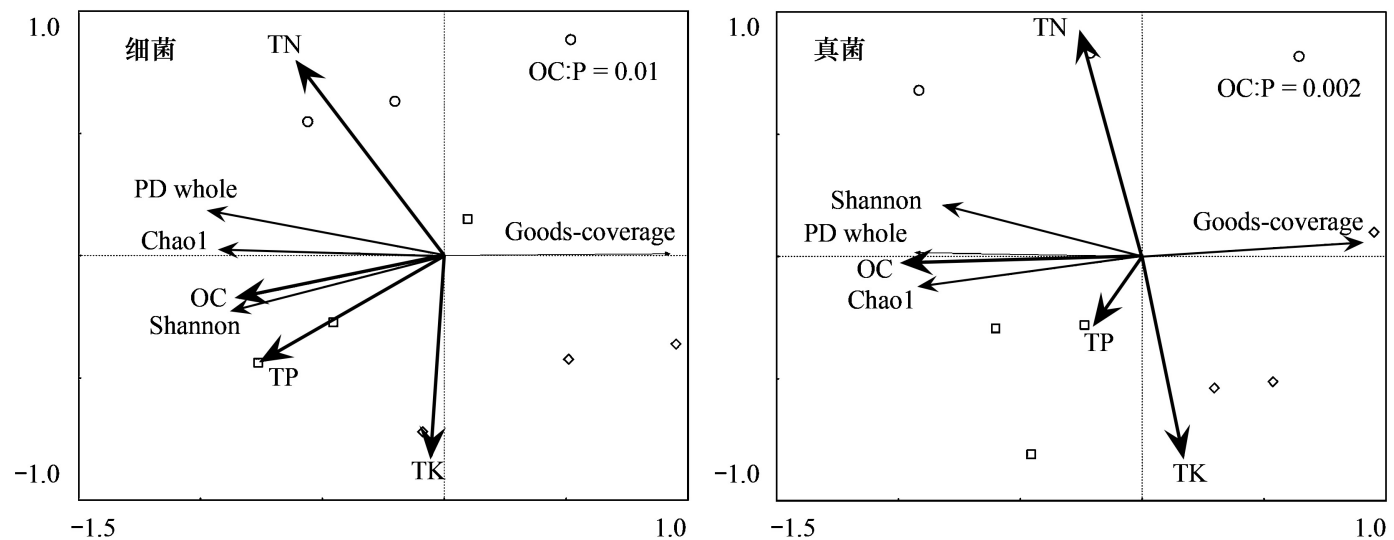

图 5 不同林分调落物中微生物多样性指数和环境因子间笛余分析

Fig.5 Redundancy analysis between microbial diversity index and environmental factors of different forest stands 


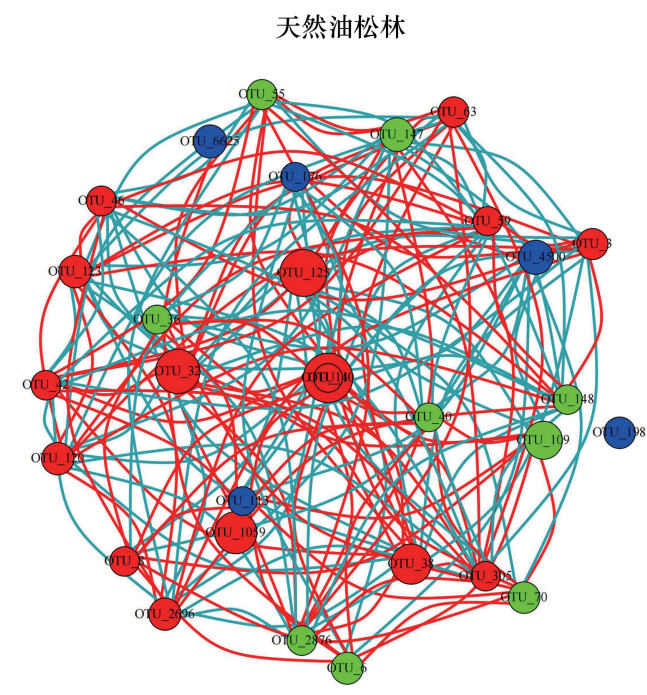

- 变形菌门 Proteobacteria

放线菌门 Actinobacteria

- 拟杆菌门 Bacteroidetes

青海云杉林

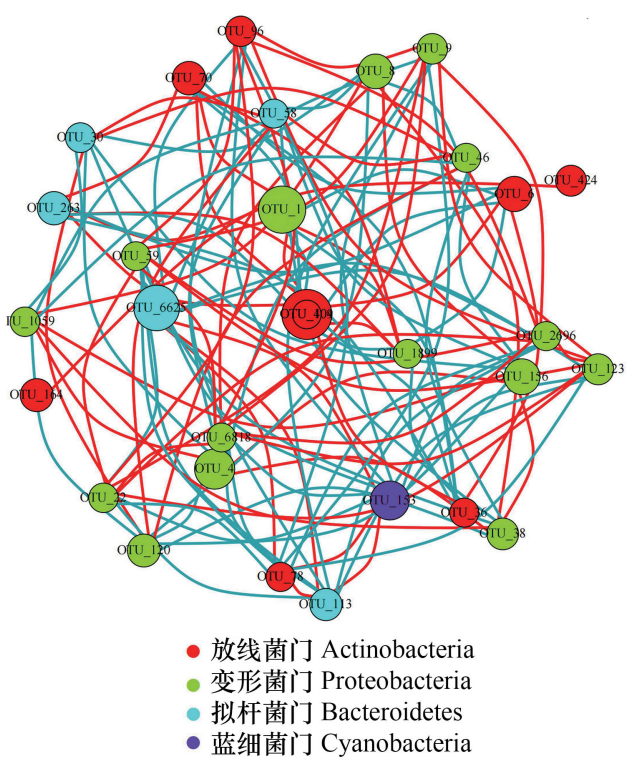

油松-山杨混交林

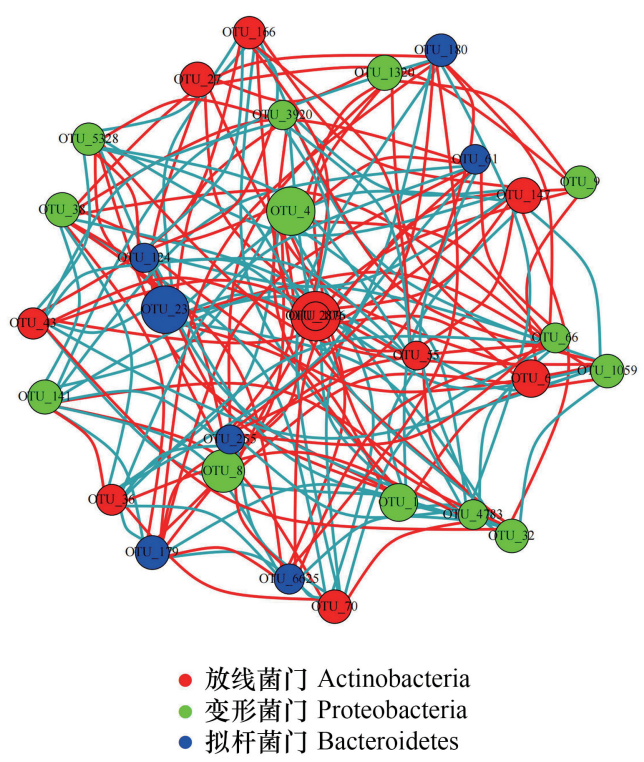

图 6 不同林分调落物细菌生态网络图

Fig.6 Bacterial ecological network diagram of litter in different forests

异, 这与当前许多研究结果并不相同 ${ }^{[32-34]}$ 。贺兰山林区以青海云杉林和油松林作为相对稳定的森林类型, 青 海云杉林具有长期郁闭、死地被物层厚等特点, 其他树种不易侵人, 是相对稳定的林分 ${ }^{[16]}$ 。油松林由于其耐 旱及抵抗力较强的特点, 在其它树种不易生长的贫瘦坡地上, 稳定性也高。因此, 贺兰山森林植物物种多样性 偏低, 枯落物来源单一, 其成分绝大多数是油松、云杉的叶片调落物。这表明林分特征没有显著影响凋落物微 生物多样性和群落结构。

林下调落物的分解过程是养分释放过程 ${ }^{[35]}$, 不同林分调落物因种类和质量有差别, 引起调落物的分解速 率不同, 由此导致不同林分土壤 OC 等含量不同 ${ }^{[14-15,28]}$ 。已有研究表明, 调落物有机碳含量与温度呈正相关, 与海拔梯度呈相关 ${ }^{[13,35]}$ 。本研究揭示贺兰山 3 种林分调落物 OC 变化规律为油松林>针阔混交林>青海云杉 

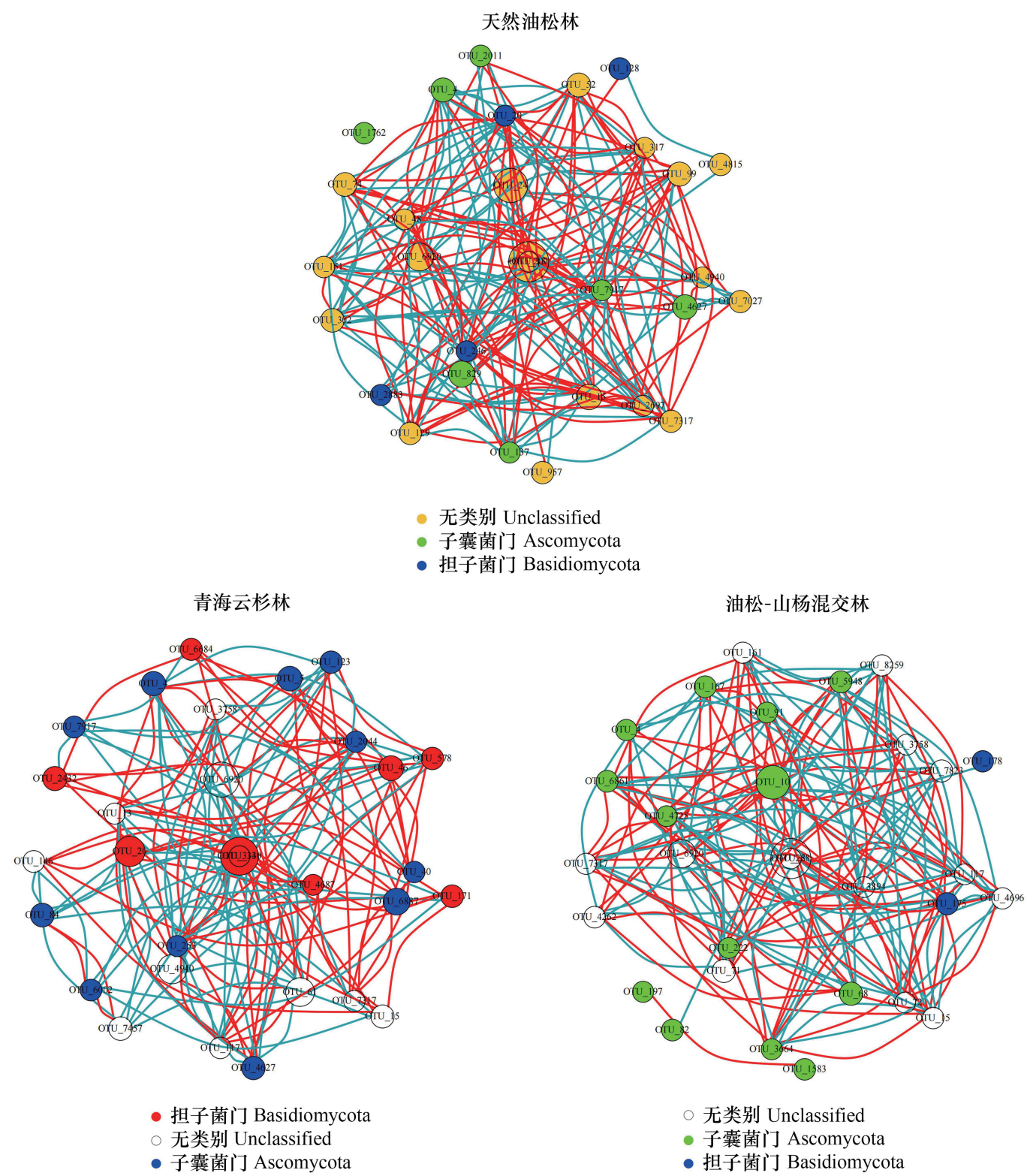

图 7 不同林分调落物真菌生态网络图

Fig.7 Ecological network map of litter fungi in different forest stands

林。这与贺兰山 3 种林分分布沿海拔梯度分布规律一致, 3 种林分凋落物 OC 含量随着海拔的升高依次递减。

细菌网络中核心节点大多属于变形菌门和放线菌门和拟杆菌门,真菌的核心节点则大多属于子囊菌门和 担子菌, 同时这几类细菌和真菌在群落中相对丰度最高, 这表明这几类细菌和真菌在调落物中占有优势地位, 对贺兰山调落物环境具有较强的适应性。此外真菌网络中的许多核心节点, 目前并无分类,却在微生物网络 的构建中发挥重要作用,将是下一步深人研究的重点。

微生物生态网络中的正相关边代表生态位一致或共生关系 ${ }^{[36]}$, 而负相关意味着生态位不同或竞争关 系 ${ }^{[37]}$ 。本研究揭示真菌间连线负相关数量略大于正相关, 细菌则相反。这是由于真菌个体数量少, 个体较 大, 生长速度较细菌慢, 并且很多种类真菌可以在油松和青海云杉根部形成外生菌根, 因此生态位不易重叠, 在生态网络中负相关比例较大 ${ }^{[38]}$ 。反之细菌个体较小, 数量多, 生态位容易重叠, 因此正相关比例较大。

许多研究揭示 $\mathrm{pH} 、 \mathrm{TN}$ 和 SOC 等环境因子对微生物群落结构影响较大 ${ }^{[7-10]}$, 而 TN 有效性对微生物生长 
有抑制作用 ${ }^{[12]}$, 本研究证明调落物 TN 与多数细菌和全部真菌属具有显著或极显著的负相关关系, 对微生物 的生长具有明显抑制作用。

\section{5 结论}

贺兰山 3 种代表性林分天然油松林、青海云杉林以及油松与山杨混交林调落物的细菌、真菌多样性指数 之间差异性均不显著, 在多样性指数中真菌 PD whole tree 指数显著大于细菌, 真菌 Shannon 指数与 Ghao1 指 数却显著小于细菌。

在门水平上贺兰山不同林分调落物的微生物优势菌类差异不显著,但在属水平上差异显著,而且细菌差 异小于真菌,在各个分类水平上, 调落物细菌和真菌群落组成均表现为油松-山杨混交林<青海云杉林 $<$ 青海云 杉林, 说明 3 种林分调落物微生物多样性在青海云杉林中最为丰富。

贺兰山油松林与油松-山杨混交林的微生物生态网络较复杂, 细菌变形菌门、放线菌门和拟杆菌门,真菌 子囊菌门和担子菌,对调落物环境更适应,对于维持微生物群落的稳定性具有重要作用。

油松林调落物的 OC 含量最大、青海云杉林调落物的 TK 含量最大、针阔混交林调落物的 TN 含量最大, 且在贺兰山 3 种林分中差异显著, 而油松林调落物的 $\mathrm{C} / \mathrm{N} 、 \mathrm{C} / \mathrm{P}$ 显著高于其他两种林分的调落物, 青海云杉林 调落物 $\mathrm{N} / \mathrm{P}$ 显著小于其他两种林分的调落物, 青海云杉林调落物 $\mathrm{N} 、 \mathrm{P}$ 含量差异最小。贺兰山 3 种林分调落 物 TN 与多数细菌和全部真菌属具显著或极显著负相关性, 对微生物的生长具有明显抑制作用, 调落物 OC、 TN、TP、TK 是影响微生物群落组成和多样性的重要因素, 其中 OC 与微生物群落多样性相关性最显著, 是影 响调落物细菌和真菌群落组成和多样性最主要的因子。

\section{参考文献 (References) :}

[ 1 ] 赵海燕. 川南 3 种林分调落物分解及生化特性研究 [D ]. 成都: 四川农业大学, 2012.

[ 2 ] 立天宇, 康峰峰, 韩海荣, 高晶, 宋小帅, 于舒, 赵金龙, 于晓文. 冀北辽河源自然保护区土壤微生物碳代谢对阔叶林叶调落物组成的响 应. 应用生态学报, 2015, 26(3): 715-722.

[ 3 ] 王晶苑, 张心昱, 温学发, 王绍强, 王辉民. 氮沉降对森林土壤有机质和调落物分解的影响及其微生物学机制. 生态学报, 2013, 33(5): 1337-1346.

[ 4 ] Cotrufo M F, Soong J L, Horton A J, Campbell E E, Haddix M L, Wall D H, Parton W J. Formation of soil organic matter via biochemical and physical pathways of litter mass loss. Nature Geoscience, 2015, 8(10): 776-779.

[ 5 ] Perry D A, Oren R, Hart S C. Forest Ecosystems. 2nd ed. Baltimore: John Hopkins University Press, 2008.

[ 6 ] Dixon R K, Solomon A M, Brown S, Houghton R A, Trexier M C, Wisniewski J. Carbon pools and flux of global forest ecosystems. Science, 1994, 263(5144) : 185-190.

[ 7 ] 罗达, 刘顺, 史作民, 冯秋红, 刘千里, 张利, 黄泉, 何建社. 川西亚高山不同林龄云杉人工林土壤微生物群落结构. 应用生态学报, 2017, 28(2) : 519-527.

[ 8 ] Chu H Y, Neufeld J D, Walker V K, Grogan P. The influence of vegetation type on the dominant soil bacteria, archaea, and fungi in a low arctic tundra landscape. Soil Science Society of America Journal, 2011, 75(5): 1756-1765.

[ 9 ] 字洪标, 向泽宇, 王根绪, 阿的鲁䩀, 王长庭. 青海不同林分土壤微生物群落结构 (PLFA). 林业科学, 2017, 53(3): 21-32.

[10] Griffiths B S, Ritz K, Ebblewhite N, Dobson G. Soil microbial community structure: effects of substrate loading rates. Soil Biology and Biochemistry, 1998, 31(1): 145-153.

[11] Craine J M, Morrow C, Fierer N. Microbial nitrogen limitation increases decomposition. Ecology, 2007, 88( 8) : 2105-2113.

[12] Djukic I, Zehetner F, Mentler A, Gerzabek M H. Microbial community composition and activity in different Alpine vegetation zones. Soil Biology and Biochemistry, 2010, 42(2): 155-161.

[13] Liu D, Keiblinger K M, Leitner S, Mentler A, Zechmeister-Boltenstern S. Is there a convergence of deciduous leaf litter stoichiometry, biochemistry and microbial population during decay? Geoderma, 2016, 272: 93-100.

[14] 马胜兰, 吴鹏飞. 增温对森林土壤有机碳含量的影响. 西南农业学报, 2019, 32(6): 1335-1339.

[15] Piao S L, Fang J Y, He J S. Variations in vegetation net primary production in the Qinghai-Xizang Plateau, China, from 1982 to 1999. Climatic Change, 2006, 74(1) : 253-267. 
[16] 刘秉儒, 张秀珍, 胡天华, 李文金. 贺兰山不同海拔典型植被带土壤微生物多样性. 生态学报, 2013, 33(22)：7211-7220.

[17］赵晓春. 贺兰山典型森林类型调落物层水文效应研究 $[D]$. 杨凌: 西北农林科技大学, 2011.

[18］刘秉儒, 璩向宁, 李志刚, 胡天华. 贺兰山森林生态系统长期定位研究的重大意义与研究内容. 宁夏农林科技, 2010, (1): 53- 54, 58-58.

[19］刘秉儒. 生态数据分析与建模. 银川: 宁夏人民教育出版社, 2019.

[20］李振高, 骆永明, 滕应. 土壤与环境微生物研究法. 北京: 科学出版社, 2008.

[21] Caporaso J G, Lauber C L, Walters W A, Berg-Lyons D, Lozupone C A, Turnbaugh P J, Fierer N, Knight R. Global patterns of 16S rRNA diversity at a depth of millions of sequences per sample. Proceedings of the National Academy of Sciences of the United States of America, 2011, $108(\mathrm{~S} 1)$ : 4516-4522.

[22] Youssef N, Sheik C S, Krumholz L R, Najar F Z, Roe B A, Elshahed M S. Comparison of species richness estimates obtained using nearly complete fragments and simulated pyrosequencing-generated fragments in 16S rRNA gene-based environmental surveys. Applied and Environmental Microbiology, 2009, 75(16): 5227-5236.

[23] Hess M, Sczyrba A, Egan R, Kim T W, Chokhawala H, Schroth G, Luo S J, Clark D S, Chen F, Zhang T, Mackie R I, Pennacchio L A, Tringe S G, Visel A, Woyke T, Wang Z, Rubin E M. Metagenomic discovery of biomass-degrading genes and genomes from cow rumen. Science, 2011, $331(6016): 463-467$.

[24] 张文文. 贺兰山不同林分枯落物与土壤的微生物群落特征研究 $[\mathrm{D}]$. 银川: 宁夏大学, 2020.

[25] Bengtsson-Palme J, Ryberg M, Hartmann M, Branco S, Wang Z, Godhe A, De Wit P, Sánchez-García M, Ebersberger I, De Sousa F, Amend A S, Jumpponen A, Unterseher M, Kristiansson E, Abarenkov K, Bertrand Y J K, Sanli K, Eriksson K M, Vik U, Veldre V, Nilsson R H. Improved software detection and extraction of ITS1 and ITS2 from ribosomal ITS sequences of fungi and other eukaryotes for analysis of environmental sequencing data. Methods in Ecology and Evolution, 2013, 4(10): 914-919.

[26］牛宋芳. 荒漠草原不同土壤类型人工柠条林根际微生物群落结构及多样性特征研究 [D]. 银川: 宁夏大学, 2018.

[27] Aßhauer K P, Wemheuer B, Daniel R, Meinicke P. Tax4Fun: predicting functional profiles from metagenomic 16S rRNA data. Bioinformatics, $2015,31(17): 2882-2884$.

[28] Urbanová M, Šnajdr J, Baldrian P. Composition of fungal and bacterial communities in forest litter and soil is largely determined by dominant trees. Soil Biology and Biochemistry, 2015, 84: 53-64.

[29] 周永娜, 乔沙沙, 刘晋仙, 贾粀, 李㲗, 柴宝峰, 张乃桢, 梁昭江. 庞泉沟自然保护区华北落叶松与桦树林土壤微生物群落结构. 应用与 环境生物学报, 2017, 23(3): 520-526.

[30] Ma B, Dai Z M, Wang H Z, Dsouza M, Liu X M, He Y, Wu J J, Rodrigues J L M, Gilbert J A, Brookes P C, Xu J M. Distinct biogeographic patterns for archaea, bacteria, and fungi along the vegetation gradient at the continental scale in Eastern China. mSystems, 2017, 2(1): e00174-16.

[31］陈秀波, 朱德全, 赵晨晨, 张路路, 陈立新, 段文标. 不同林型红松林土壤真菌群落组成和多样性. 土壤学报, 2019, 56(5)：1221-1234.

[32] 董爱荣, 吕国忠, 吴庆禹, 宋瑞清, 宋福强. 小兴安岭凉水自然保护区森林土壤真菌的多样性. 东北林业大学学报, 2004, 32(1): 8- 10.

[33] Lejon D P H, Chaussod R, Ranger J, Ranjard L. Microbial community structure and density under different tree species in an acid forest soil (Morvan, France). Microbial Ecology, 2005, 50(4): 614-625.

[34] 郑裕雄, 曹际玲, 杨智杰, 林成芳, 杨玉盛. 氮沉降对亚热带常绿阔叶天然林不同季节土壤微生物群落结构的影响. 土壤学报, 2018, 55 (6) : 1534-1544

[35] 刘强, 彭少麟. 植物调落物生态学. 北京: 科学出版社, 2010.

[36] Berry D, Widder S. Deciphering microbial interactions and detecting keystone species with co-occurrence networks. Frontiers in Microbiology, 2014, 5: 219 .

[37] Faust K, Raes J. Microbial interactions: from networks to models. Nature Reviews Microbiology, 2012, 10(8) : 538-550.

[38] 焦克, 张旭博, 徐梦, 刘晓洁, 安前东, 张崇玉. 藏东南典型暗针叶林不同土壤剖面微生物群落特征. 生态学报, 2021, 41 (12)： 4864-4875 